\title{
Hubungan Antara Dukungan Sosial Orang Tua dengan Motivasi Belajar Siswa SDK St. Ursula Ende
}

\author{
Maria Finsensia Ansel \\ Program Studi Pendidikan Guru Sekolah Dasar Universitas Flores \\ mariafinsensiaansel@gmail.com
}

Siti Arafat

Program Studi Pendidikan Guru Sekolah Dasar Universitas Flores sitiarafat@gmail.com

\begin{abstract}
This study aims to determine the relationship between parental social support and learning motivation of elementary school students. This research was correlational research with a quantitative approach. The population in this study were students of SDK St. Ursula, amounting to 435 people and the sample were 80 students in 5 and 6 grades with a purposive sampling technique. The data collection method used a questionnaire with the measuring instrument that consisted of the scale of parents' social support and the scale of student learning motivation. Data analysis was carried out by using product moment correlation which was calculated using SPSS version 26. The results showed the $r$ value of 0.624, which means that there is a significant positive relationship between parents' social support and student learning motivation at SDK St. Ursula where the higher the parents 'social support, the higher the learning motivation of elementary school students, and conversely the lower the parents' social support, the lower the learning motivation of elementary school students.
\end{abstract}

Keyword: Parental social support, motivation to learn.

\section{Pendahuluan}

Pendidikan memiliki peran penting dalam kehidupan manusia dan sebagai pondasi perkembangan kemajuan suatu bangsa. Namun kenyataan yang terjadi selama sepekan ini dengan adanya pandemi Corona Virus Disease 2019 (Covid-19) yang melanda hampir semua bangsa termasuk bangsa Indonesia membuat pendidikan di Indonesia sedikit mengalami kendala nasional. Covid-19atau yang dikenal dengan nama virus Corona merupakan penyakit atau virus menular yang baru ditemukan yang menyerang siapa saja seperti lansia, anak-anak hingga orang dewasa dan bisa menyebabkan gangguan ringan pada sistem pernapasan, infeksi paru-paru yang berat hingga kematian. Virus corona ini membawa dampak yang sangat pesat terhadap perubahan kehidupan bangsa-bangsa di dunia termasuk bangsa Indonesia. Perubahan nampak dalam berbagai bidang kehidupan seperti bidang ekonomi, transportasi, pendidikan, pariwisata dan lain sebagainya.

Khusus pada bidang pendidikan terjadi perubahan yang sangat besar dalam sistem pembelajaran dimana sistem pembelajaran yang biasanya berlangsung di kelas melalui tatap muka antara guru dan siswa dengan adanya covid-19, proses tatap muka dihentikan demi memutus mata rantai penyebaran covid-19. Sistem pembelajaran yang biasanya terjadi di kelas digantikan dengan sistem pembelajaran daring (dalam jaringan). Pembelajaran daring merupakan sistem pembelajaran tanpa tatap muka secara langsung antara guru dan siswa tetapi 
dilakukan melalui online yang menggunakan jaringan internet. Guru harus memastikan kegiatan belajar tetap berjalan meskipun siswa berada di rumah.

Hal ini sesuai dengan surat edaran Menteri Pendidikan dan Kebudayaan Nomor 4 Tahun 2020 tentang Pelaksanaan kebijakan pendidikan dalam Masa Darurat Penyebaran Corona Virus Disease (Covid-19). Sistem pembelajaran dilaksanakan melalui perangkat personal computer (PC) atau laptop yang terhubung dengan koneksi jaringan internet. Guru dapat melakukan pembelajaran yang sama diwaktu yang sama menggunakan grup di media sosial seperti whatsapp (WA), telegram, instragam, aplikasi zoom ataupun media lainnya sebagai media pembelajaran. Dengan demikian guru dapat memastikan siswa mengikuti pembelajaran dalam waktu yang sama dengan tempat yang berbeda. Sistem pembelajaran daring dapat berjalan dengan lancar bila siswa memiliki motivasi untuk belajar. Agar dapat mencapai tujuan maka siswa harus memiliki motivasi untuk belajar.

Motivasi belajar menurut Winkel (2014) merupakan keseluruhan daya penggerak psikis dalam diri siswa yang menimbulkan kegiatan belajar, serta memberikan arah pada kegiatan belajar demi mencapai suatu tujuan. Selanjutnya, Arifudin (2009) menyatakan siswa yang memiliki motivasi belajar yang tinggi cenderung menunjukkan sikap semangat dan gairah dalam mengikuti proses pembelajaran. Kelihatan siswa lebih bersungguh-sungguh, perhatian dan aktif dalam mengikuti kegiatan belajar mengajar baik di kelas maupun di luar kelas.

Keberhasilan belajar dapat dilihat dalam motivasi belajar yang ditunjukkan oleh siswa pada saat pelaksanaan kegiatan belajar. Adapun aspek-aspek motivasi belajar menurut Sudjana (2005) yaitu minat dan perhatian siswa terhadap pelajaran, semangat siswa untuk melakukan tugas-tugasnya, tanggung jawab siswa dalam mengerjakan tugasnya, reaksi yang ditunjukan oleh siswa terhadap stimulus yang diberikan guru, dan rasa senang dan puas dalam mengerjakan tugas-tugas yang diberikan. Sementara faktor-faktor motivasi belajar meliputi faktor intrinsik berupa hasrat dan keinginan berhasil dan dorongan kebutuhan belajar, harapan akan cita-cita. Sedangkan faktor ekstrinsiknya berupa adanya penghargaan, lingkungan belajar yang kondusif, dan kegiatan belajar yang menarik (Uno, 2012).

Motivasi belajar intrinsik sangat penting dalam keberhasilan belajar siswa sendiri. Jika siswa memiliki motivasi belajar dalam dirinya yang kuat maka akan semakin tinggi tingkat keberhasilan belajar karena siswa memiliki minat, niat dan perhatian yang tinggi terhadap pelajarannya. Namun, bukan berari bahwa motivasi belajar ekstrinsik tidak diperlukan. Motivasi belajar ekstrinsik tetap diperlukan karena dalam belajar keadaan siswa yang dinamis dan cepat berubahubah dan adanya hal-hal yang kurang menarik bagi siswa dalam belajar maka diperlukan juga motivasi ekstrinsik atau motivasi dari orang lain seperti keluarga. Untuk itu salah satu faktor yang menunjang keberhasilan belajar juga dipengaruhi oleh dukungan sosial seperti guru, orangtua dan teman sebaya. Dalam penelitian ini lebih difokuskan pada dukungan sosial orang tua.

Dukungan sosial dari keluarga dalam hal ini orang tua sangat penting selama masa pandemi Covid-19 ini. Peranan orangtua dalam mendukung kegiatan belajar siswa di rumah menjadi bagian yang sangat penting untuk keberhasilan belajar siswa selama covid-19. Menurut Gunarsa (2004) dorongan belajar kepada anak bisa diartikan sebagai usaha aktif orang tua, baik itu secara langsung maupun tidak langsunng. Secara langsung dilakukan dengan mengajarkan proses belajar kepada anak untuk menunjang keberhasilannya. Secara tidak langsung, orang tua dapat menumbuhkan motivasi belajar anak dengan memberikan bimbingan pada anak 
dalam proses belajar. Jadi orang tua tidak hanya menyuruh anak untuk belajar, tetapi juga berperan membimbing anak pada saat anak belajar.

Menurut Rook, dukungan sosial sebagai salah satu fungsi pertalian sosial yang menggambarkan tingkat dan kualitas umum dari hubungan interpersonal yang akan melindungi individu dari konsekuens stres. Dukungan sosial yang diterima dapat membuat individu merasa tenang, diperhatikan, timbul rasa percaya diri, dan kompeten. Tersedianya dukungan sosial akan membuat individu merasa di cintai dan dihargai dan menjadi bagian dari kelompok (Pontoh dan Farid, 2015). Untuk itu dukungan sosial orang tua memiliki peranan yang sangat penting bagi anak-anaknya. Apabila orang tua tidak memberikan perhatian lebih pada anakanaknya maka akan sangat mempengaruhi keberhasilan anak dalam kehidupannya termasuk keberhasilan dalam menempuh pendidikan.

Dukungan sosial merupakan suatu cara atau sarana yang sangat efektif dalam membantu individu pada masa-masa sulit, dukungan yang diberikan individu dapat beraneka ragam. Menurut Weiss (Maslihah, 2011) dukungan sosial orang tua dibagi kedalam enam bagian yaitu: guidance (bimbingan), reliable alliance (aliansi yang dapat diandalkan), attachment (kasih sayang dan cinta), reassurance of worth (jaminan nilai), social integration (integrasi sosial), dan opportunity to provide nurturance (kesempatan untuk memberikan pengasuhan). Komponen-komponen ini dikelompokkan ke dalam dua bentuk yaitu instrumental support dan emotional support. Sementara menurut Sarafino (Astuti dan Budiyani, 2010) ada 4 bentuk dukungan sosial yaitu dukungan emosional, dukungan penghargaan, dukungan instrumental, dan dukungan informatif.

Menurut Sarason (Nurmalasari dan Putri, 2015) individu dengan dukungan sosial yang tinggi memiliki pengalaman hidup yang lebih baik, harga diri yang lebih tinggi, serta memiliki pandangan yang lebih positif terhadap kehidupan dibandingkan individu dengan dukungan sosial yang rendah. Sebaliknya dukungan sosial yang rendah memberikan ketidakpuasan hidup dan hambatan-hambatan dalam melakukan tugas-tugas dan pekerjaan sehari-hari. Dari pandangan ini, maka dapat disimpulkan bahwa dukungan sosial dari orangtua dapat memberikan efek positif dan juga negatif bagi siswa. Efek positifnya yaitu menumbuhkan semangat, minat dan perhatian siswa untuk belajar. Sedangkan efek negatifnya yaitu apabila dukungan yang diberikan itu tidak sesuai dengan kebutuhan siswa, memberikan contoh yang buruk dan tidak memberikan dukungan pada siswa untuk belajar.

Penelitian ini dilakukan di SDK St. Ursula berdasarkan observasi dan wawancara yang dilakukan oleh penulis diketahui bahwa pada masa pandemi covid-19 mulai bulan Maret 2020 sampai dengan akhir tahun 2020 proses belajar dilaksanakan dari rumah. SDK St. Ursula juga menerapkan sistem pembelajaran daring dengan memanfaatkan jaringan internet baik itu melalui whatsapp, youtube dan aplikasi e-learning moodle dengan tujuan agar proses belajar tetap terlaksana meskipun tidak berada di sekolah.

Namun, dari hasil wawancara dengan guru kelas diketahui bahwa banyak siswayang masih kaku dan ada beberapa anak yang tidak aktif dengan tugas-tugas yang diberikan oleh guru, ada sebagian anak yang tidak mengerjakan tugas yang diberikan oleh guru. Menurut guru kelas, banyak alasan anak tidak aktif dalam pembelajaran daring seperti anak yang belum siap dengan proses belajar dari rumah, kurangnya pengawasan dan bimbingan dari orang tua pada saat anak belajar dari rumah dikarenakan orangtua yang juga sibuk bekerja, dan banyak orang tua yang mengeluhkan bahwa anak tidak mengikuti aturan orangtua atau anak susah di atur jika orang tua yang memberikan bimbingan dan beberapa anak 
mengeluhkan orang tua yang tidak memiliki paket internet sehingga mengalami keterlambatan dalam pengiriman tugas. Guru kelas mengatakan sistem pembelajaran daring akan berjalan dengan baik jika adanya dukungan yang tinggi dari orang tua untuk mensukseskan pembelajaran selama anak di rumah.

Hasil wawancara dan pengamatan yang dilakukan dengan beberapa orang tua diketahui bahwa orangtua sangat kewalahan dalam membimbing anak di rumah karena anak kadang tidak mau dibimbing orang tua dan beban pekerjaan orangtua yang banyak membuat orang tua tidak siap dalam membimbing anak-anaknya belajar dari rumah. Ada beberapa orangtua yang menyatakan bahwa mereka sudah berusaha memberikan dukungan terhadap pelaksanaan pembelajaran daring yaitu dengan membimbing anak-anak mengerjakan tugas-tugas yang harus dikerjakan, namun anak sering tidak patuh terhadap orang tua dimana anak sering membanding-bandingkan cara orang tua membimbing dengan cara guru memberikan bimbingan dalam belajar sehingga orangtua kadang lelah dalam menghadapi anak, karena kesibukan yang dimiliki oleh orangtua ada beberapa orang tua yang tidak peduli dengan anak dan tidak memberikan dukungan terhadap pembelajaran anak, Untuk lebih memperkuat permasalahan, peneliti melakukan wawancara terhadap beberapa siswa di SDK St. Ursula. Hasil wawancara dengan beberapa anak menyatakan bahwa selama masa pandemi ini mereka merasa bosan dengan pembelajaran yang hanya berlangsung di rumah, dimana anak menyatakan bahwa orangtua mereka yang sibuk bekerja membuat mereka tidak mendapat perhatian dan kadang orangtua tidak peduli terhadap tugas-tugas sekolah yang diberikan oleh guru, pada saat anak menyelesaikan tugas-tugas yang diberikan oleh guru, namun ada beberapa anak yang menyatakan bahwa orangtua mendampingi dan membimbing mereka pada saat menyelesaikan tugas yang diberikan oleh guru, dan ada orangtua yang tidak memberikan peralatan belajar yang dibutuhkan anak untuk mendukung pelaksanaan pembelajaran, anak juga mengeluhkan pada saat orangtuanya sibuk anak tidak diberikan informasi-informasi yang berkaitan dengan kegiatan pembelajaran daring sehingga anak tidak menyelesaikan tugas-tugas yang diberikan oleh guru dengan baik, orangtua juga tidak menghargai hasil belajar yang ditunjukkan oleh anak dimana jarang memberikan pujian jika anak berhasil menyelesaikan soalsoal yang diberikan oleh guru.

Berdasarkan fenomena di atas, maka penulis melakukan penelitian tentang hubungan antara dukungan sosial orang tua dengan motivasi belajar siswa di SDK St. Ursula Ende.

\section{Metode}

Jenis penelitian yang digunakan adalah penelitian korelasional tentang hubungan antara dukungan sosial orang tua dengan motivasi belajar siswa sekolah dasar. Populasi dalam penelitian ini adalah siswa SDK St. Ursula Ende kelas 1 sampai dengan kelas 6 yang berjumlah 435 siswa sedangkan sampel dalam penelitian ini adalah siswa kelas 5 dan 6 yang berjumlah 80 orang dengan teknik pengambilan sampelnya adalah purposive sampling. Menurut Sugiyono (2016:85) bahwa purposive sampling adalah teknik pengambilan sampel sumber data dengan pertimbangan tertentu. Sehingga dalam penelitian ini pertimbangan pemilihansampelnya yaitu siswa kelas 5 dan 6 merupakan siswa kelas tinggi yang sudah mampu memahami cara pengisian angket dan dapat membaca dengan lancar, siswa kelas 5 dan 6 dengan tingkatan pembelajaran yang semakin sulit sehingga memerlukan dukungan yang besar dari orang tua untuk belajar dan motivasi belajar yang tinggi dari siswa. 
Metode pengumpulan data dalam penelitian ini menggunakan angket. Angket dalam penelitian ini disusun dengan menggunakan skala Likert 1-4. Dalam skala Likert digunakan pernyataan yang favorable atau positif dengan kriteria $1=$ Sangat Tidak Setuju (STS), 2 = Tidak Setuju (TS), 3=Setuju (S), dan 4=Sangat Setuju (SS). Sementara untuk pernyataan yang unfavorable atau negatif dengan kriteria 1=Sangat Setuju (SS), 2=Setuju (S), 3=Tidak Setuju (TS) dan 4=Sangat Tidak Setuju (STS). Instrumen dalam penelitian ini ada dua yaitu skala dukungan sosial orang tua dan skala motivasi belajar siswa.

Skala dukungan sosial orang tua yang digunakan dalam penelitian ini yaitu dukungan dukungan emosional, dukungan penghargaan, dukungan instrumental, dan dukungan informatif (Sarafino, 1998). Skala ini telah di mofifikasi oleh penulis sesuai dengan kebutuhan dalam penelitian ini.

Tabel 1. Blueprint skala dukungan sosial orang tua

\begin{tabular}{|c|c|c|c|c|c|}
\hline No & Aspek & Indikator & Favorable & Unfavorable & Jumlah \\
\hline \multirow[t]{2}{*}{1} & \multirow{2}{*}{$\begin{array}{l}\text { Dukungan } \\
\text { Emosional }\end{array}$} & a. Ungkapan rasa empati & 1,9 & 2,6 & 4 \\
\hline & & $\begin{array}{l}\text { b. Kepedulian dan } \\
\text { perhatian }\end{array}$ & $\begin{array}{c}3,5,7,22 \\
13\end{array}$ & 4,8 & 7 \\
\hline \multirow[t]{2}{*}{2} & \multirow{2}{*}{$\begin{array}{l}\text { Dukungan } \\
\text { penghargaa } \\
\mathrm{n}\end{array}$} & a. Ungkapan penghargaan & $10,14,18$ & 15,19 & 5 \\
\hline & & $\begin{array}{l}\text { b. Ungkapan hormat } \\
\text { orangtua terhadap } \\
\text { prestasi anak }\end{array}$ & $12,16,20$ & 17,21 & 5 \\
\hline \multirow[t]{2}{*}{3} & \multirow[t]{2}{*}{$\begin{array}{l}\text { Dukungan } \\
\text { instrumenta } \\
1\end{array}$} & $\begin{array}{l}\text { a. Bantuan nyata yang } \\
\text { dapat diberikan orang } \\
\text { tua dapat berpa barang }\end{array}$ & $\begin{array}{c}22,26,28 \\
32,34\end{array}$ & 23,27 & 7 \\
\hline & & $\begin{array}{l}\text { b. Bantuan yang diberikan } \\
\text { orang tua dalam bentuk } \\
\text { jasa }\end{array}$ & 24,30 & 25,29 & 4 \\
\hline \multirow[t]{3}{*}{4} & \multirow{3}{*}{$\begin{array}{l}\text { Dukungan } \\
\text { informatif }\end{array}$} & a. Sarana dan nasehat & $31,35,39$ & 36,40 & 5 \\
\hline & & b. Petunjuk atau informasi & 33,37 & 38 & 3 \\
\hline & & Total & 25 & 15 & 40 \\
\hline
\end{tabular}

Dari 40 item pernyataan skala dukungan sosial orangtua yang diujikan kepada siswa sekolah dasar SDK Paupire yang merupakan sekolah satu gugus dengan sekolah yang akan dilakukan penelitian, setelah dilakukan uji coba atau try out dinyatakan bahwa semua item pernyataan yaitu sebanyak 40 item pernyataan dinyatakan valid dengan nilai kisaran validitasnya berkisar antara 0,388 sampai dengan 0,817 yang artinya bahwa semua 40 item pernyataan dapat digunakan untuk mengukur dukungan sosial orang tua. Sementara hasil ujicoba dari 40 item pernyataan yang valid juga dilakukan uji reliabilitas dari 40 item pernyataan dengan nilai reliabilitasnya sebesar 0,943 artinya sangat reliabel untuk mengukur dukungan sosial orangtu terhadap siswa.

Selanjutnya skala motivasi belajar yang digunakan dalam penelitian ini di adaptasi oleh penulis dari teori Sudjana (2015) dan dimodifikasi oleh penulis sesuai dengan kebutuhan pada penelitian ini. Skala ini dirancang pada aspek-aspek motivasi belajar yaitu menunjukkan minat dan perhatian siswa terhadap belajar, semangat siswa untuk melakukan tugas-tugasnya, reaksi yang ditunjukkan siswa terhadap stimulus yang diberikan dan rasa senang dan puas dalam mengerjakan tugas-tugas yang diberikan. Berikut ini tabel blue print skala motivasi belajar. 
Tabel 2. Blue print skala motivasi belajar

\begin{tabular}{clcc}
\hline No & \multicolumn{1}{c}{ Aspek } & \multicolumn{1}{c}{ Favorable } & Unfavorable \\
\hline 1 & $\begin{array}{l}\text { Minat dan perhatian terhadap } \\
\text { pelajaran }\end{array}$ & $1,3,5,7,9$ & $2,4,6,8$ \\
\hline 2 & Semangat dalam melakukan tugas & $10,12,14,16$ & $11,13,15$ \\
\hline 3 & $\begin{array}{l}\text { Rasa senang dan puas dalam } \\
\text { mengerjakan tugas }\end{array}$ & $17,19,21,23,25$ & 18,20 \\
\hline 4 & $\begin{array}{l}\text { Tanggung jawab dalam mengerjakan } \\
\text { tugas belajar }\end{array}$ & $22,24,26,28$ & 27,29 \\
\hline 5 & $\begin{array}{l}\text { Reaksi yang ditunjukkan terhadap } \\
\text { stimulus }\end{array}$ & $30,32,34,36,39$ & $31,33,35,37,38,40$ \\
\hline \multicolumn{1}{c}{ Total } & 23 & 17 \\
\hline
\end{tabular}

Skala motivasi belajar dengan jumlah 40 item pernyataan setelah dilakukan uji coba atau try out instrumen angket dinyatakan bahwa semua item pernyataan skala motivasi belajar dinyatakan valid dengan nilai kisaran validnya yaitu 0,370 sampai dengan 0,787 yang berarti item pernyataan angket motivasi belajar dapat digunakan untuk melakukan penelitian. Sementara nilai reliabilitasnya sebesar 0,941 berarti skala dukungan sosial orangtua sangat reliabel.

Teknik analisis data yang digunakan dalam penelitian ini adalah teknik korelasi product moment yang dalam perhitungannya menggunakan bantuan SSPS versi 26.00. Analisis data dilakukan untuk menguji analisis deskriptif dan uji hipotesis.

\section{Hasil}

Analisis deskriptif dilakukan untuk memberikan gambaran mean, nilai minimum, nilai maksimum, dan standar deviasi dari variabel dukungan sosial orang tua dan motivasi belajar siswa.Berikut ini tabel hasil uji analisis deskriprif variabel dukungan sosial orang tua dan motivasi belajar siswa di SDK St. Ursula Ende yaitu sebagai berikut.

Tabel 3. Hasil uji statistik deskriptif variabel dukungan sosial orang tua dan variabel motivasi belajar siswa di SDK St. Ursula

\begin{tabular}{lcc}
\hline & Dukungan Sosial Orangtua & Motivasi belajar siswa \\
\hline Mean & 130.10 & 130.89 \\
\hline Median & 131.00 & 135.00 \\
\hline Std. Deviation & 17.978 & 14.711 \\
\hline Minimum & 71 & 96 \\
\hline Maximum & 160 & 160 \\
\hline
\end{tabular}

Sumber : hasil pengolahan SPSS

Diketahui bahwa variabel dukungan sosial orang tua dari 80 siswa diperoleh nilai mean sebesar 130,10, nilai median sebesar 131, standar deviasi sebesar 17,978 dengan nilai minimum yaitu 71 dan nilai maksimumnya 160 . Sementara untuk variabel motivasi belajar diketahui nilai mean sebesar 130,89 , nilai mediannya 135 , standar deviasi sebesar 14,711 dengan nilai minimum sebesar 96 dan nilai maksimum sebesar 160.Berikut ini tabel gambaran kategori dukungan sosial keluarga.

Tabel 4. Kategori dukungan sosial orang tua di SDK St. Ursula

\begin{tabular}{lccc}
\hline \multicolumn{1}{c}{ Kategori } & Frequency & Percent & Cumulative Percent \\
\hline Rendah & 1 & 1.3 & 1.3 \\
\hline Sedang & 4 & 5.0 & 6.3 \\
\hline Tinggi & 75 & 93.8 & 100.0 \\
\hline Total & 80 & 100.0 & \\
\hline Sumber: hasil pengolahan SPSS & & &
\end{tabular}


Tabel 4 di atas merupakan kategori variabel dukungan sosial orang tua diketahui bahwa 1 orang siswa berada pada kategori rendah dengan persentase 1,3\%, 4 orang siswa di kategori sedang dengan persentase $5 \%$ dan 75 orang berada pada kategori tinggi dengan persentase 93,8\%. Disimpulkan bahwa dukungan sosial orang tua siswa di SDK St. Ursula berada pada kategori tinggi. Sedangkan untuk variabel motivasi belajar, dapat dilihat pada tabel berikut ini.

Tabel 5. Kategori motivasi belajar siswa di SDK St. Ursula

\begin{tabular}{|c|c|c|c|}
\hline Kategori & Frequency & Percent & Cumulative Percent \\
\hline Rendah & 1 & 1.3 & .3 \\
\hline Sedang & 17 & 21.3 & 22.5 \\
\hline Tinggi & 62 & 77.5 & 100.0 \\
\hline Total & 80 & 100.0 & \\
\hline
\end{tabular}

Sumber: hasil pengolahan SPSS

Tabel 5 menunjukkan bahwa kategori motivasi belajar siswa dari 80 orang siswa, 1 orang siswa berada pada kategori rendah dengan persentase 1,3\%, 17 orang siswa berada pada kategori sedang dengan persentase $21,3 \%$ dan 62 orang siswa berada pada kategori tinggi dengan persentase 77,5\%. Jadi dapat disimpulkan bahwa motivasi belajar siswa di SDK St. Ursula umumnya berada pada kategori tinggi.

Hasil perhitungan analisis korelasi product moment dengan menggunakan bantuan SPSS versi 26.00 dapat dilihat pada tabel berikut.

Tabel 6. Hasil ujihipotesis dukungan sosial orang tua dengan motivasi belajar siswa SDK St. Ursula Ende

\begin{tabular}{|c|c|c|c|}
\hline \multicolumn{4}{|c|}{ Correlations } \\
\hline & & $\begin{array}{c}\text { Dukungan Sosial } \\
\text { Orangtua }\end{array}$ & Motivasi belajar siswa \\
\hline \multirow{3}{*}{$\begin{array}{c}\text { Dukungan Sosial } \\
\text { Orangtua }\end{array}$} & Pearson Correlation & 1 & $.624^{* *}$ \\
\hline & Sig. (2-tailed) & & .000 \\
\hline & $\mathrm{N}$ & 80 & 80 \\
\hline \multirow{3}{*}{$\begin{array}{l}\text { Motivasi belajar } \\
\text { siswa }\end{array}$} & Pearson Correlation & $.624^{* *}$ & 1 \\
\hline & Sig. (2-tailed) & .000 & \\
\hline & $\mathrm{N}$ & 80 & 80 \\
\hline
\end{tabular}

**. Correlation is significant at the 0.01 level (2-tailed).

Sumber: hasil pengolahan SPSS

Tabel 6 menunjukkan bahwa antara dukungan sosial orang tua dengan motivasi belajar di peroleh nilai Sig. (2-tailed) atau $\rho$-value $=0,00(<0,05)$. Hasil ini menunjukkan bahwa ada hubungan yang signifikan antara dukungan sosial orang tua dengan motivasi belajar siswa SDK St. Ursula Ende dengan nilai korelasi $\mathrm{r}_{\mathrm{xy}}=$ 0,624. Jadi hipotesis ha diterima yaitu ada hubungan yang signifikan antara dukungan sosial orangtua dengan motivasi belajar siswa di SDK St. Ursula Ende. Dukungan sosial orangtua yang diberikan sebesar $62,4 \%$ terhadap motivasi belajar siswa hal ini menunjukkan bahwa persentase dukungan sosial orangtua besar terhadap motivasi belajar, dan sisanya $37,6 \%$ dipengaruhi oleh variabel lainnya.

\section{Pembahasan}

Hasil penelitian yang dilakukan oleh Emeralda dan Kristiana (2017) menunjukkan bahwa ada hubungan positif antara variabel dukungan sosial orang tua dengan variabel motivasi belajar pada siswa sekolah menengah pertama. Hal ini berarti bahwa semakin tinggi dukungan sosial orang tua maka semakin tinggi motivasi belajar pada siswa sekolah menengah pertama, begitu juga sebaliknya. Begitu pula penelitian yang dilakukan oleh Prasetyo dan Rahmasari (2016) menunjukkan adanya hubungan positif yang signifikan antara dukungan sosial keluarga dengan motivasi belajar pada siswadi SMP Negeri 11 Kota Pasuruan. 
Berdasarkan hasil penelitian terdahulu dan penelitian yang dilakukan oleh penulis maka diketahui bahwa dukungan sosial orang tua memiliki hubungan dengan motivasi belajar siswa. Seperti pendapat Sarason (Nurmalasari dan Putri, 2015) individu dengan dukungan sosial yang tinggi memiliki pengalaman hidup yang lebih baik, harga diri yang lebih tinggi, serta memiliki pandangan yang lebih positif terhadap kehidupan dibandingkan individu dengan dukungan sosial yang rendah. Sebaliknya dukungan sosial yang rendah memberikan ketidakpuasan hidup dan hambatan-hambatan dalam melakukan tugas-tugas dan pekerjaan sehari-hari. Jadi, dukungan sosial sangat penting dalam memberikan semangat kepada siswa untuk belajar.

Pengukuran dukungan sosial orang tua dilakukan berdasarkan pendapat atau teori Sarafino (1998) yang menunjukkan ada empat bentuk dukungan sosial orang tua yaitu dukungan emosional, dukungan penghargaan, dukungan instrumental, dan dukungan informatif. Dukungan emosional berupa ungkapan rasa empati, kepedulian dan perhatian. Dukungan penghargaan berupa ungkapan penghargaan dan ungkapan hormat orangtua terhadap prestasi anak. Dukungan instrumental berupa bantuan nyata yang dapat diberikan orang tua berupa barang dan jasa. Dukungan informatif berupa sarana dan nasehat serta petunjuk atau informasi. Empat bentuk dukungan sosial ini setelah dilakukan penelitian maka dapat diketahui bahwa dukungan sosial orang tua di SDK St. Ursula berada pada kategori tinggi dimana dari 80 orang siswa 75 orang siswa mendapatkan dukungan sosial orangtua yang tinggi.

Motivasi belajar adalah keseluruhan daya penggerak didalam diri siswa yang menimbulkan kegiatan belajar, yang menjamin kelangsungan dari kegiatan belajar dan memberikan arah pada kegiatan belajar sehingga tujuan yang dikehendaki subjek belajar itu dapat tercapai (Sadirman, 2011). Pengukuran motivasi belajar didasarkan pada teori Sudjana (20015) yaitu aspek-aspek motivasi belajar yaitu perhatian siswa terhadap pelajaran, semangat siswa untuk meakukan tugastugasnya, tanggung jawabsiswa dalam mengerjakan tugasnya, reaksi yang ditunjukan oleh siswa terhadap stimulus yang diberikan guru, dan rasa senang dan puas dalam mengerjakan tugas-tugas yang diberikan. Hasil pengukuran skala motivasi belajar siswa SDK St. Ursula dari 80 orang siswa menunjukkan bahwa 62 siswa berada pada kategori motivasi belajar tinggi. Hal ini berarti bahwa motivasi belajar siswa di SDK St. Ursula Ende tinggi.

Hasil penelitian menunjukkan bahwa nilai korelasi product moment atau nilai $\mathrm{r}$ adalah 0,624. Hasil ini menunjukkan bahwa ada hubungan yang signifikan antara dukungan sosial orang tua dan motivasi belajar siswa di SDK St. Ursula yaitu semakin tinggi dukungan yang diberikan orangtua maka semakin tinggi pula motivasi belajar siswa dan begitu juga sebaliknya.

\section{Simpulan}

Hasil penelitian menunjukkan bahwa nilai korelasi product moment atau nilai $\mathrm{r}$ sebesar 0,624 menunjukkan ada hubungan yang signifikan antara dukungan sosial orang tua dan motivasi belajar siswa di SDK St. Ursula dimana semakin tinggi dukungan sosial orang tua semakin tinggi pula motivasi belajar siswa dan sebaliknya semakin rendah dukungan sosial orang tua semakin rendah pula motivasi belajar siswanya.

\section{Saran}

Berdasarkan hasil penelitian maka disarankan kepada pihak sekolah untuk terus meningkatkanrelasi atau komunikasi dengan orang tua siswa secara lebih intensif 
untuk mendukung motivasi belajar siswa guna mencapai tujuan belajar. Pihak orang tua di masa pandemi covid-19 diharapkan terus meningkatkan dukungan terhadap anak sehingga anak lebih termotivasi dalam belajar dan tujuan belajar dapat tercapai. Pihak guru diharapkan terus meningkatkan motivasi belajar kepada siswa dan menjalin komunikasi dengan orang tua sehingga orang tua dapat memberikan dukungan selama anak belajar dari rumah selama pandemi covid-19 ini sementara untuk peneliti selanjutnya diharapkan dapat menjadi referensi untuk meneliti faktor-faktor lainnya yang mempengaruhi motivasi belajar siswa.

\section{Referensi}

Astuti, Apri and Budiyani, Kondag. (2010). Hubungan Antara Dukungan Sosial Yang Diterima Dengan Kebermaknaan Hidup Pada Odha (Orang Dengan Hiv/Aids). Insight Jurnal Ilmiah Psikologi, 8(2). ISSN 1693-2552

Arifudin. (2009). Metode Penelitian Kualitatif. Bandung: CV Pustaka Setia.

Dhitaningrum, M., \& Izzati, U. A. (2013). Hubungan antara persepsi mengenai dukungan sosial orang tua dengan motivasi belajar siswa SMA Negeri 1 Gondang Kabupaten Tulungagung. Jurnal Penelitian Psikologi, 1(2).

Emeralda, N.G \& Kristiana, F.I. (2017). Hubungan Antara Dukungan Sosial Orang Tua Dengan Motivasi Belajar Siswa Sekolah Menengah Pertama. Jurnal Empati, 7(3), 154-159.

Gunarsa, S. D. (2004). Psikologi Perkembangan Anak dan Remaja. Jakarta: Gunung Mulia.

Listiyani. (2019). Hubungan Antara Dukungan Sosial Orang Tua Dengan Kepercayaan Diri. Journal for Lesson and Learning Studies, 2(1), 10-20.

Maslihah, S. (2011). Studi tentang Hubungan Dukungan Sosial, Penyesuaian Sosial di Lingkungan Sekolah dan Prestasi Akademik Siswa SMPIT Assyfa Boarding School Subang Jawa Barat. Jurnal Psikologi Undip, 10(2), 103-114.

Nurmalasari, Y. \& Putri, E.D. (2015). Dukungan Sosial dan Harga Diri Pada Remaja Penderita Lupus. Jurnal Psikologi, 8(1), 46-51.

Prasetyo, B.K \& Rahmasari, D. 2016. Hubungan Antara Dukungan Sosial Keluarga Dengan Motivasi Belajar Pada Siswa. Jurnal Penelitian Psikologi, 7(1), 1-9.

Pontoh, Z. dan Farid, M. (2015). Hubungan Antara Religiulitas dan Dukungan Sosial dengan Kebahagiaan Pelaku Konversi Agama. Persona, Jurnal Psikologi Indonesia, 4(1), 100-110.

Sani, N. D., Fandizal, M., \& Astuti, Y. (2020). Hubungan Dukungan Sosial Orang Tua Dengan Motivasi Belajar Mahasiswa Keperawatan. Jurnal Keperawatan Widya Gantari Indonesia 4(2), 110-114.

Sardiman, A. M. (2011). Interaksi dan Motivasi Belajar Mengajar. Jakarta: PT. Raja Grafindo Persada.

Suciani, D. \& Rozali, Y. A. (2014). Hubungan Dukungan Sosial Dengan Motivasi Belajar Pada Mahasiswa Universitas Esa Unggul. Jurnal Psikologi, 12(2), 4347.

Sudjana, N. (2005). Penilaian Hasil Proses Belajar Mengajar. Bandung: PT. Remaja Rosdakarya.

Sugiyono. (2012). Metode Penelitian Kuantitatif Kualitatif dan R\&D. Bandung: Alfabeta.

Surat Edaran Menteri Pendidikan dan Kebudayaan Nomor 4 Tahun 2020 tentang Pelaksanaan kebijakan pendidikan dalam Masa Darurat Penyebaran Corona Virus Disease (Covid-19).

Uno, H. B. (2012). Teori Motivasi dan Pengukurannya. Jakarta: PT. Bumi Aksara.

Winkel, W. S. (2014). Psikologi Pengajaran. Jakarta: Grasindor. 